\title{
Seasonal and spatial variability in egg production and biomass of Calanus finmarchicus around Iceland
}

\author{
Astthor Gislason* \\ Marine Research Institute, Skulagata 4, 121 Reykjavik, Iceland
}

\begin{abstract}
A summary of data on the reproductive biology of Calanus finmarchicus from winter to summer is presented for the years 1996 to 2002. Egg production rates, clutch size, gonad development stage, female body size and female abundance were measured in conjunction with food availability in the different oceanographic domains around the island. The egg production rates varied both seasonally and spatially. SW of Iceland, spawning of $C$. finmarchicus started earlier on the shelf (April) than in the open sea (May). In this area, the period of appreciable reproductive activity also lasted longer onshore ( $\sim 3 \mathrm{mo}$, April to June) than offshore ( 2 mo, May to June). On the SW shelves, monthly means of egg production rates were highest in June ( 45 eggs female $\left.{ }^{-1} \mathrm{~d}^{-1}\right)$, whereas in offshore areas the highest rates were observed in May ( 35 eggs female $\left.{ }^{-1} \mathrm{~d}^{-1}\right)$. The best spatial coverage is provided by the May data, when average egg production rates were higher north and east of Iceland $\left(\sim 35\right.$ eggs female $\left.{ }^{-1} \mathrm{~d}^{-1}\right)$ than off the south and west coasts $\left(\sim 26\right.$ eggs female $\left.{ }^{-1} \mathrm{~d}^{-1}\right)$. In contrast, the average biomass of $C$. finmarchicus was lower off the north $\left(\sim 360 \mathrm{mg} \mathrm{C} \mathrm{m}^{-2}\right)$ and east coasts $\left(\sim 810 \mathrm{mg} \mathrm{C} \mathrm{m}^{-2}\right)$, as compared to off the south and west coasts $\left(\sim 1660 \mathrm{mg} \mathrm{C} \mathrm{m}^{-2}\right)$, suggesting that factors such as predation or advection were important in dictating the distribution of biomass in these areas. Multiple regression analysis showed that over the large spatial and temporal scales of the present study, the egg production rates were positively related to food conditions (chlorophyll a) and female size, but not to temperature. Specific egg production rates were used to estimate secondary production and potential grazing impact of $C$. finmarchicus in the different oceanographic domains around Iceland. The results show marked differences in secondary production and potential grazing impact of $C$. finmarchicus, both between seasons and oceanographic domains.
\end{abstract}

KEY WORDS: Calanus finmarchicus - Egg production - Gonad development - North Atlantic · Biomass $\cdot$ Secondary production $\cdot$ Grazing

Resale or republication not permitted without written consent of the publisher

\section{INTRODUCTION}

On the basis of hydrography, Icelandic waters may be divided into 3 main oceanographic domains, the Atlantic Domain to the south and west, the Atlantic/ Arctic Domain on the northern shelves and the Arctic Domain in the offshore waters to the north and NE and on the eastern shelves (S. A. Malmberg pers. comm.; see Fig. 1). This variability in hydrographic conditions affects the distribution, composition and productivity of zooplankton around the country (Gislason 2002).
The copepod Calanus finmarchicus is the dominant zooplankter, both in numbers and biomass in the Atlantic and Atlantic/Arctic Domains, whereas in the Arctic Domain, C. finmarchicus plays a less important role, where it is replaced by the closely related but much bigger arctic copepod C. hyperboreus (Astthorsson et al. 1983, Gislason 2000). The biomass distribution of C. finmarchicus around Iceland further indicates that the warmer waters of the south and west coasts may provide a more favourable environment for the growth and development of $C$. finmarchicus than 
the colder waters off the north, NE and east coasts (Astthorsson \& Gislason 1995, Gislason 2002). In addition to this spatial variability, long-term monitoring of zooplankton has shown that the biomass of zooplankton fluctuates markedly between years. Due to the dominant contribution of $C$. finmarchicus to the zooplankton biomass, it is suggested that the observed variations in total biomass may to a large extent reflect changes in the abundance and productivity of this species (Astthorsson et al. 1983, Astthorsson \& Gislason 1995, Beare et al. 2000).

The measurement of egg production rate is easy to carry out at sea, and the measured rates are relatively robust against variations in feeding conditions (Plourde \& Runge 1993, Laabir et al. 1995) and incubation temperatures (Laabir et al. 1995, Runge \& Roff 2000). The method is therefore efficient for estimating in situ reproductive rates of Calanus finmarchicus, which is a key parameter in population dynamics (Hirche 1996). Here, I use shipboard egg production experiments that were carried out on several cruises from 1996 to 2002, covering the winter, spring and summer seasons, to describe the productivity of $C$. finmarchicus in the different environments around Iceland. The broad spatial and temporal scales of the study enable analysis with respect to spatial, seasonal and year-to-year variability.

The reproductive biology of Calanus finmarchicus was reviewed by Hirche (1996). The egg production has been found to be closely related to the phytoplankton spring bloom (Marshall \& Orr 1972, Diel \& Tande 1992, Runge \& Plourde 1996, Hirche et al. 1997, Melle \& Skjoldal 1998). However, in the absence of phytoplankton, C. finmarchicus is also able to produce eggs using microzooplankton or internal lipid reserves as a source of energy (Ohman \& Runge 1994, Niehoff et al. 1999, Richardson et al. 1999). In addition to food, temperature has also been recognised as a factor that may influence egg production (Runge \& Plourde 1996, Hirche et al. 1997).

The objectives of this study were 3-fold: First, to estimate spatial and temporal variability in egg production rates of Calanus finmarchicus from incubation experiments in the waters around Iceland. Sampling was carried out over 6 yr and extended from winter to summer, allowing measurements to be made under a variety of different conditions and providing data over a broad range of temperatures $\left(-0.5^{\circ} \mathrm{C}\right.$ to $\left.10^{\circ} \mathrm{C}\right)$ and chlorophyll a concentrations ( 0 to $550 \mathrm{mg} \mathrm{m}^{-2}, 0$ to $30 \mathrm{~m}$ ). Second, to assess the relative importance of chlorophyll $a$, temperature and female size on rates of egg production. And third, to estimate spatial and temporal variability in production and potential grazing impact by C. finmarchicus, as derived from the egg production rates. The study provides the hitherto most comprehensive set of estimates of $C$. finmarchicus egg production rates from Icelandic waters.

\section{MATERIALS AND METHODS}

Material was collected on 12 cruises in 1996, 1997, 1999, 2000, 2001 and 2002. Dates of cruises and number of sampled stations are presented in Table 1. At each station a suite of hydrographic and biological measurements was made (Fig. 1).

Hydrography and chlorophyll a. Temperature and salinity were recorded with a CTD (Sea Bird Electron-

Table 1. Cruise sampling details. The number of stations where egg production rates were measured and the total number of incubations during each cruise (SW: southwest subregion [Atlantic Domain]; N: north subregion [Atlantic/Arctic Domain]; E: east subregion [Arctic Domain])

\begin{tabular}{|c|c|c|c|c|c|c|c|}
\hline \multirow[t]{2}{*}{ Cruise } & \multirow{2}{*}{ Dates } & \multicolumn{2}{|c|}{$-\mathrm{SW}$} & \multicolumn{2}{|c|}{$-\mathrm{N}-$} & \multirow{2}{*}{ Stations } & \multirow{2}{*}{$\begin{array}{l}\mathrm{E} \\
\text { Incubations }\end{array}$} \\
\hline & & Stations & Incubations & Stations & Incubations & & \\
\hline b1396 & 2-6 Dec 1996 & 4 & 8 & & & & \\
\hline b0297 & 30 Jan-6 Feb 1997 & 8 & 40 & & & & \\
\hline b0497 & 3-10 Apr 1997 & 14 & 115 & & & & \\
\hline b0797 & 19-25 Jun 1997 & 16 & 297 & & & & \\
\hline a0399 & 9-12 Apr 1999 & 13 & 234 & & & & \\
\hline b0699 & 7-12 May 1999 & 14 & 265 & & & & \\
\hline b0799 & 28 May 1999 & & & & & 1 & 18 \\
\hline b0899 & 9-15 Jun 1999 & 16 & 281 & 1 & 19 & & \\
\hline b0600 & 16-31 May 2000 & 14 & 243 & 8 & 125 & 9 & 149 \\
\hline b0700 & 13-20 Jun 2000 & 23 & 407 & 2 & 38 & & \\
\hline b0601 & 15-31 May 2001 & 26 & 411 & 17 & 261 & 16 & 304 \\
\hline b0701 & 11-16 Jun 2001 & 17 & 299 & 1 & 19 & & \\
\hline b0502 & 14-29 May 2002 & 16 & 273 & 13 & 215 & 16 & 300 \\
\hline Total & & 180 & 2873 & 42 & 677 & 42 & 771 \\
\hline
\end{tabular}




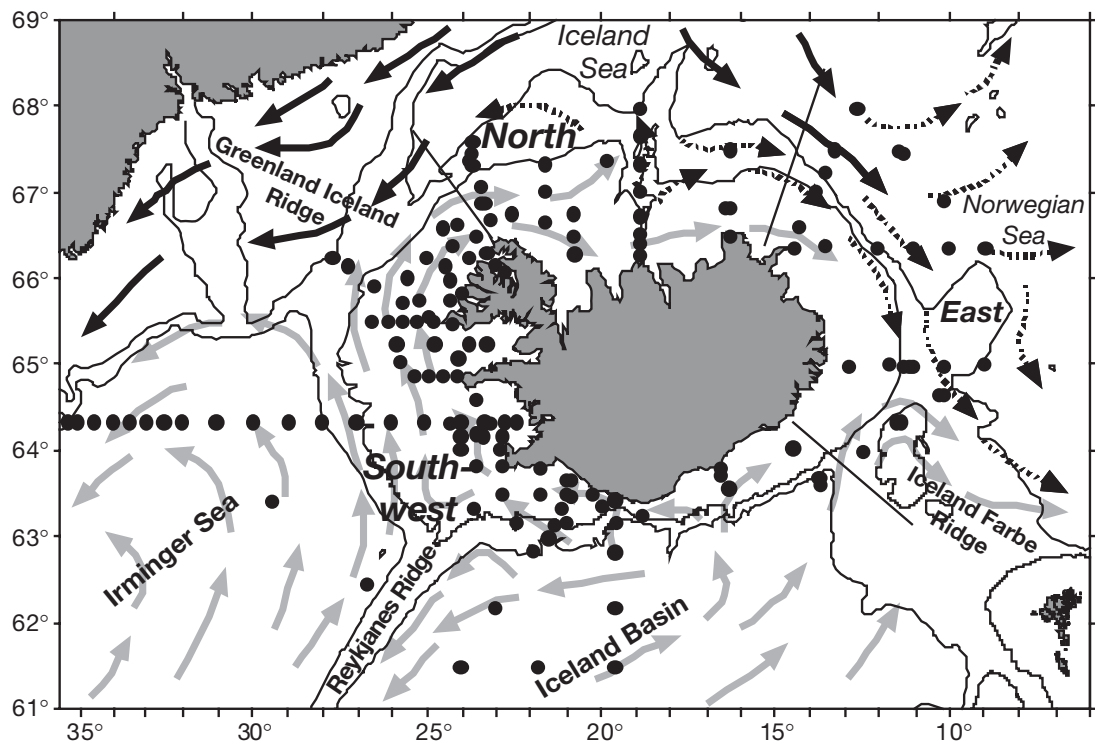

Fig. 1. Map of the study area SW of Iceland showing the sampling stations. Inserted on the figure are the main ocean currents in the upper layers, adapted from Valdimarsson \& Malmberg (1999) (grey arrows: Atlantic water; black arrows: polar water; black broken arrows: mixed water). The 400 and $1000 \mathrm{~m}$ isobaths and the division into 3 subregions (SW subregion [Atlantic Domain]; north subregion [Atlantic/Arctic Domain]; east subregion [Arctic Domain]) are also shown

ics SBE-9). Seawater samples (1 to 2 l) for the measurement of chlorophyll a were collected from depths of 10 and $30 \mathrm{~m}$, except in May 2000, when they were collected from 0 and $20 \mathrm{~m}$ depth. The seawater samples were filtered through GF/C glass fibre filters. The filters were then homogenised in $90 \%$ aqueous acetone, and the extract was measured in a spectrophotometer according to the method described by Strickland \& Parsons (1968).

Zooplankton sampling. At every station 2 vertical hauls were made from $100 \mathrm{~m}$ to the surface with a WP2 net $\left(0.25 \mathrm{~m}^{2}\right.$ mouth area, $200 \mu \mathrm{m}$ mesh size). The volume of water filtered by the net was measured with a HydroBios flowmeter fitted in the mouth of the net. One catch was preserved in $4 \%$ neutralised formalin for later determination of abundance in the laboratory, while the other (obtained with a nonfiltering cod-end) was used to collect live female Calanus finmarchicus for on-board egg production experiments (see 2 subsections below).

Analysis of formalin-preserved samples. The formalin-preserved samples were dealt with in the following manner: samples containing less than $\sim 400$ Calanus finmarchicus were counted from whole samples. Otherwise they were subsampled with a Motoda splitter (Motoda 1959), and, in aliquots containing at least 200 individuals, C. finmarchicus was counted and classed to developmental stages. In addition to this, the gonad maturity of the females was determined. When possi- ble, at least 30 females selected randomly from each sample were stained with borax carmine solution, dehydrated and stored in glycerine. The gonad development was classified into 4 stages (G1, G2, G3, G4), of which the last characterises mature females ready to spawn (Niehoff \& Hirche 1996).

Egg production experiments. The live copepod samples were gently emptied into a $\sim 151$ bucket containing surface water. From this bucket females of Calanus finmarchicus were immediately taken with a large pipette and transferred to Petri dishes, where females in good condition were quickly sorted out (usually within $1 \mathrm{~h}$ after capture) using a stereomicroscope with cold fibre optic light. Females were placed into egg production chambers of Plexiglas $(65 \mathrm{~mm}$ in diameter, $180 \mathrm{~mm}$ in height) with a funnel at the bottom into which the eggs settled. A $330 \mu \mathrm{m}$ net separated the cylinder from the funnel, which prevented $C$. finmarchicus from eating its own eggs. One female was added to each chamber, and whenever possible 20 replicates were done per station. However, due to the paucity of females at some stations (especially during the winter cruises: December, January, February) and the fact that some experiments had to be discarded because of dead or moribund females, the experiments were sometimes run with fewer animals (Table 1 ). The egg production chambers were incubated for $24 \mathrm{~h}$ in the dark at ambient surface water temperatures. After incubation the eggs were filtered onto a $20 \mu \mathrm{m}$ screen on which they were counted immediately under a stereomicroscope. The prosome length of the females was measured with an ocular micrometer.

For each station, mean egg production rates were calculated by dividing the number of eggs spawned during the $24 \mathrm{~h}$ incubation by the total number of incubated females whether they spawned or not, while clutch sizes were estimated by dividing the number of eggs spawned by the number of spawning females only (Runge \& Roff 2000).

Runge \& Plourde (1996) have suggested that cannibalism may occur in egg production chambers even if these are fitted with nets to separate eggs and females. However, they also noted that this source of error is most apparent when groups of females are incubated together. As we always incubated individual females and further as the experiments were run in a relatively large volume of water, I do not consider that cannibalism will influence the results presented here. 
Variations in egg production rates within stations as compared to between stations, and also between regions, were investigated by a nested ANOVA with area (Atlantic, Atlantic/Arctic and Arctic Domains; Fig. 1) as a fixed factor and stations (each with up to 20 replicates) nested within areas. The analysis was carried out using data collected during May (3 yr of data), when all 3 regions were sampled (Table 1 ). The analysis revealed a highly significant variability both between areas ( $\mathrm{p}<$ $0.01)$ and stations $(p<0.01)$. Similarly, when the analysis was carried out with data sampled in the Atlantic Domain only (4 yr of data, Table 1), split up according to if they were sampled onshore $(<400 \mathrm{~m})$ or offshore ( $>400 \mathrm{~m}$ ) (stations again as subgroups, each with up to 20 replicates), the analysis confirmed a highly significant ( $p<0.01$ ) onshore-offshore variability and also a highly significant $(p<0.01)$ variability between stations. Based on this, it is concluded that for the comparisons made in the present investigation, the variability within stations for daily egg production rates can safely be ignored.

Dry weight and carbon content. The body mass of the different developmental stages was taken from the literature or from dry weight measurements carried out as part of this study. For the females, the dry weight was calculated separately for each station from length-weight regression $\left(\mathrm{DW}_{\mathrm{mg}}=0.0148 \mathrm{PL}_{\mathrm{mm}}{ }^{2.5298}\right.$, $\mathrm{n}=87, \mathrm{r}^{2}=0.30, \mathrm{p}<0.01$ ), whereas for the other developmental stages mean values were used (Table 2). Dry weight was converted to carbon biomass assuming carbon content to be $50 \%$ of dry weight. For eggs, the biomass was taken to be $0.23 \mu \mathrm{g}$ C (Ohman \& Runge 1994).

Calculation of Calanus finmarchicus production and grazing. The daily egg production rates were converted to carbon-specific growth rates by assuming the female carbon weights and egg weights described above. The production of $C$. finmarchicus was estimated from the egg production by multiplying daily weight-specific egg production rates with total biomass, thus assuming that the specific egg production rates of the females are equal to the somatic growth of the juveniles (Berggreen et al. 1988, Laabir et al. 1995, Hirche et al. 2001, Madsen et al. 2001).

Table 2. Calanus finmarchicus. Dry weights ( $\mu$ g) of copepodite stages used in calculations of biomass and production

\begin{tabular}{|lcl|}
\hline Stage & Weight $(\mu \mathrm{g})$ & Source \\
\hline C1 & 3 & Longhurst \& Williams (1992) \\
C2 & 6 & Longhurst \& Williams (1992) \\
C3 & 20 & Longhurst \& Williams (1992) \\
C4 & 76 & Present study \\
C5 & 143 & Present study \\
C6 female & $125-245$ & Present study \\
C6 male & 216 & Present study \\
\hline
\end{tabular}

The carbon requirement of Calanus finmarchicus was calculated based on the production estimate, assuming a gross growth efficiency of $33 \%$ (Hansen et al. 1997). The potential grazing impact of $C$. finmarchicus was calculated by dividing the carbon requirement by the integrated phytoplankton biomass (0 to $30 \mathrm{~m}$ ). Chlorophyll was converted to carbon using a carbon to chlorophyll ratio of 50, which is a reasonable value for phytoplankton in Icelandic waters (K. Gudmundsson pers. comm.).

Study area and hydrography. Iceland is located in the northern part of the North Atlantic at the junction of 2 great submarine ridge systems, the Mid-Atlantic Ridge and the Greenland-Scotland Ridge (Fig. 1). The ridges have a decisive influence on the flow of ocean currents and the distribution of water masses around Iceland. The Greenland-Scotland Ridge is particularly important in this respect, since it acts as a barrier that constrains flow between the relatively warm waters of the North Atlantic and the cold arctic deep waters of the Iceland and Norwegian Seas. The biological oceanography south and north of Iceland is therefore very different.

A branch of the North Atlantic Current carries warm and saline Atlantic Water towards the south and west coasts of Iceland (Stefansson 1962, Valdimarsson \& Malmberg 1999, Hansen \& Østerhus 2000; Fig. 1). In the Denmark Strait, on reaching the GreenlandIceland Ridge, the current splits into 2 components, the larger one turns westwards and enters the cyclonic circulation in the Irminger Sea, while the smaller branch continues northwards to the North Icelandic continental shelf area, where it mixes with cold Polar Water coming from the north. Through cooling of this mixture an arctic water mass is formed, which flows as the East Icelandic Current south-eastwards along the North Icelandic continental slope and southwards along the eastern slope. Over the Iceland-Faroe Ridge, the East Icelandic Current meets the warmer North Atlantic Current coming from the south in a frontal area that stretches south-eastwards from the eastern banks along the northern slope of the Iceland-Faroe Ridge.

\section{RESULTS}

\section{Chlorophyll a}

During the winter (December to March), depth-integrated (0 to $30 \mathrm{~m}$ ) chlorophyll a values were very low (<4 mg chl a m${ }^{-2}$; Fig. 2). In April, spring growth of the phytoplankton began closest to the coast ( $\sim$ to $160 \mathrm{~m}$ chl a $\mathrm{m}^{-2}$ ), whereas hardly any growth had begun off-

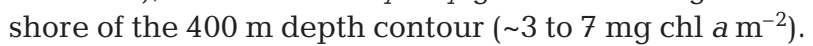
By May, phytoplankton biomass had increased, and 

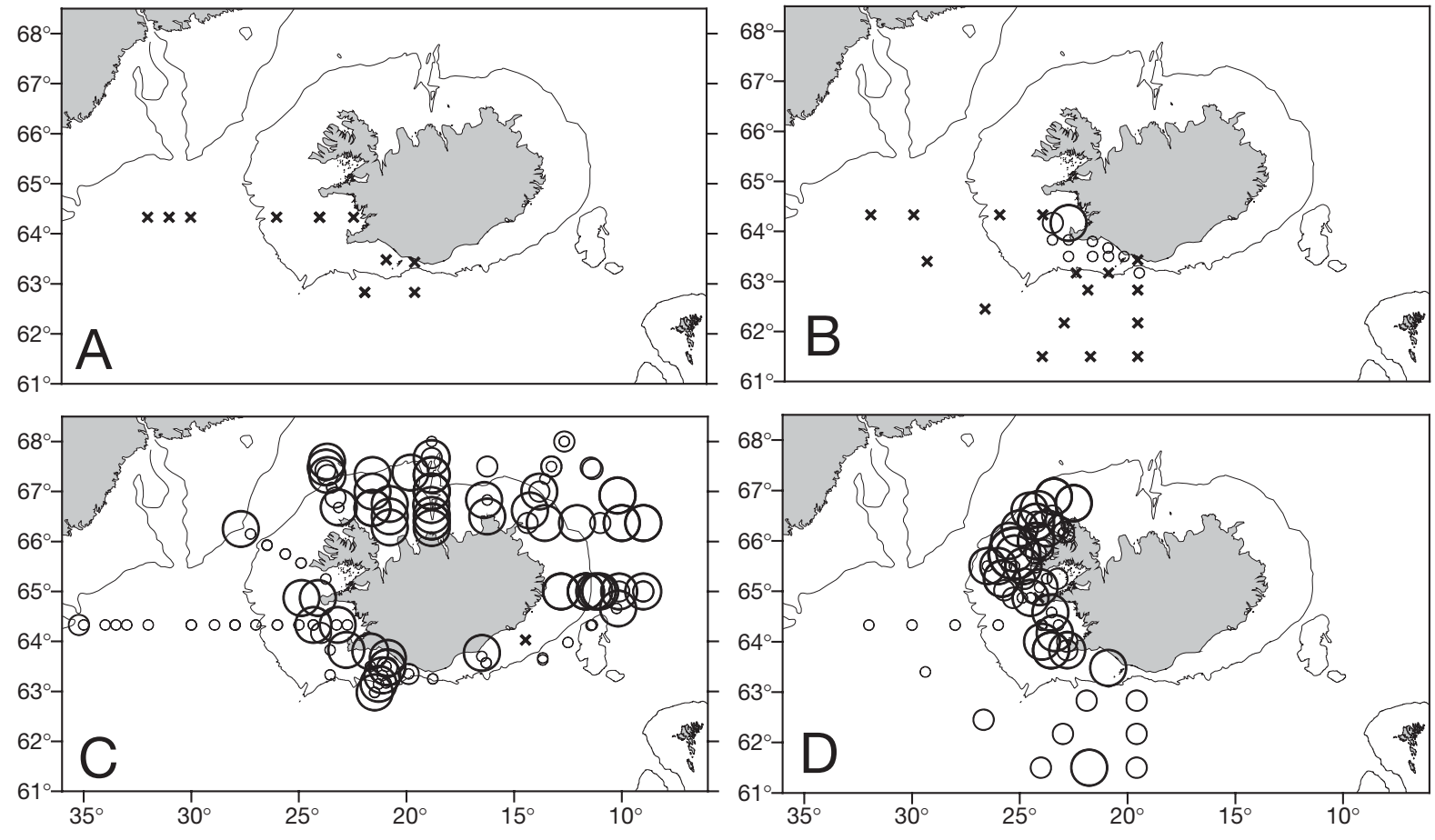

$\times 0$ to $10 \bigcirc 10$ to $50 \bigcirc 50$ to $100 \bigcirc 100$ to $500 \bigcirc 500$ to 1000

Fig. 2. Distribution of chlorophyll a $\left(\mathrm{mg} \mathrm{m}^{-2}\right.$, integrated for 0 to $30 \mathrm{~m}$ ) around Iceland, 1996 to 2002, during (A) winter (December to February), (B) April, (C) May and (D) June. The $400 \mathrm{~m}$ isobath is also shown

more so in the nearshore waters $(\sim 10$ to $340 \mathrm{mg}$ chl a $\mathrm{m}^{-2}$ ) than in the offshore areas ( 10 to $150 \mathrm{mgchl} a$ $\mathrm{m}^{-2}$ ). By June, the biomass of phytoplankton SW and west of Iceland had increased considerably, especially

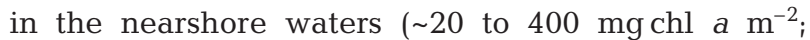
Fig. 2).

\section{Reproduction}

The geographical distributions of daily egg production rates of Calanus finmarchicus from winter to summer are shown in Fig. 3. During winter, essentially no egg production was observed ( $<1$ egg female ${ }^{-1} \mathrm{~d}^{-1}$; Fig. 3A). In April, egg production had started on the SW bank (range for all bank stations 0 to 31 eggs female ${ }^{-1}$ $\mathrm{d}^{-1}$; Fig. 3B), whereas hardly any egg production was observed in the offshore area $\left(<2\right.$ eggs female $\left.{ }^{-1} \mathrm{~d}^{-1}\right)$. In May, daily rates of egg production were relatively high, both on the shelf and in the offshore area (range for all stations 0 to 87 eggs female ${ }^{-1} \mathrm{~d}^{-1}$; Fig. 3C). During this time, the highest egg production rates $(>60$ eggs female $\mathrm{e}^{-1} \mathrm{~d}^{-1}$ ) were generally observed on the SW, northern and eastern shelves, and in the offshore areas west and east of the country, whereas the values tended to be relatively low $\left(<10\right.$ eggs female $\left.{ }^{-1} \mathrm{~d}^{-1}\right)$ in the oceanic areas northeast of Iceland. By June, daily egg production rates on the western shelf were considerably higher than in May ( 40 to 90 eggs female ${ }^{-1}$ $\mathrm{d}^{-1}$ ), whereas the egg production rates on the SW banks and in the oceanic Irminger Sea had decreased from the previous month $\left(<20\right.$ eggs female ${ }^{-1} \mathrm{~d}^{-1}$; Fig. 3D).

The temporal development of chlorophyll a concentrations and various reproductive parameters of Calanus finmarchicus (stage structure, proportion of mature females, proportion of spawning females, clutch size, daily egg production rates) tended to be different on the shelves and in the open ocean. I have therefore divided the data between those collected on the shelves $(<400 \mathrm{~m})$ and those taken beyond them ( $>400 \mathrm{~m}$; Fig. 4). As the best coverage in time is provided by the data collected south and west of Iceland (Atlantic Domain; Table 1, Fig. 3), Fig. 4 only shows data from that area.

The average chlorophyll concentrations were always higher on the shelf than farther from shore (Fig. 4A). In both environments, the biomass of chlorophyll a was 

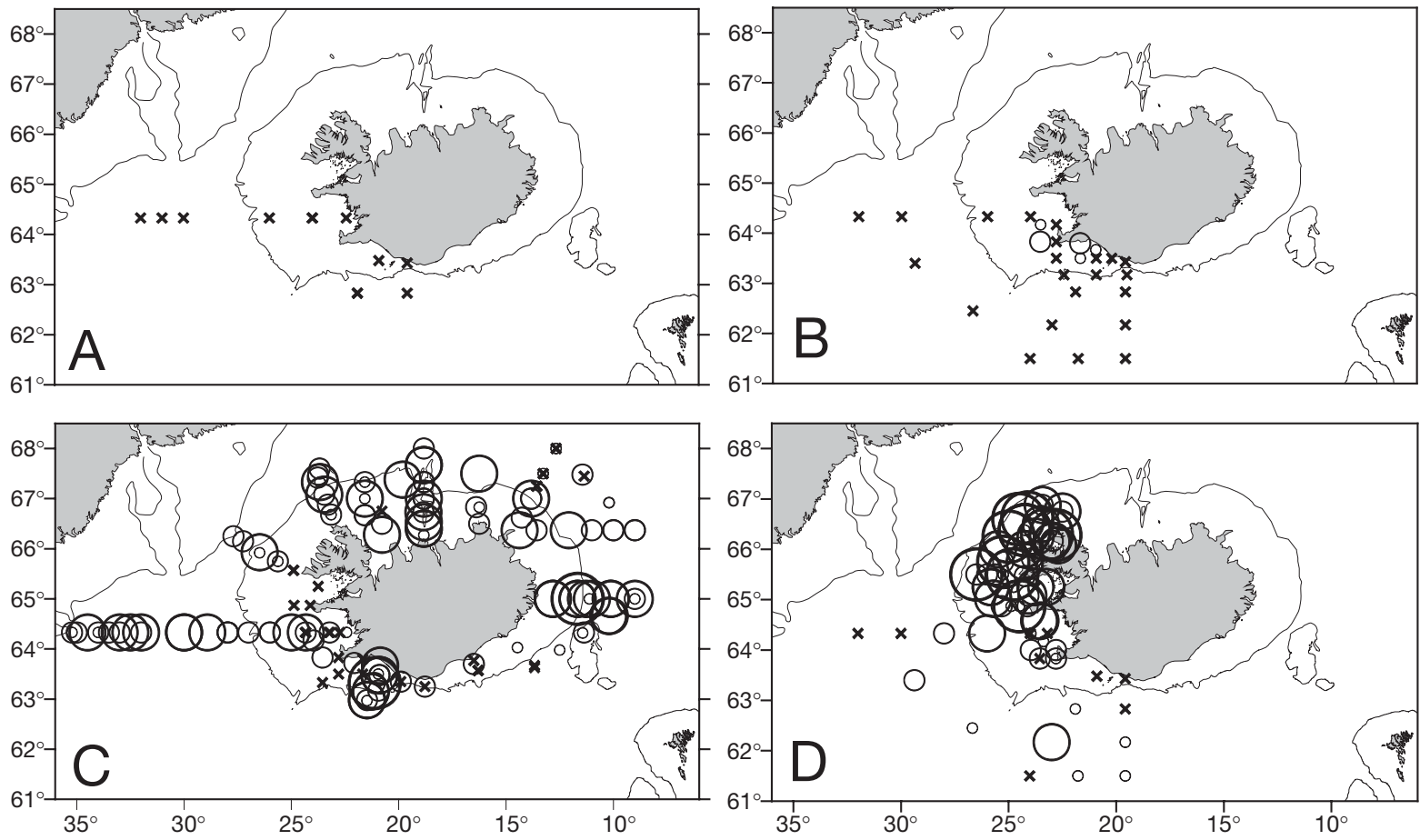

$$
\text { X } 0 \text { to } 10 \text { ○ } 10 \text { to } 20 \bigcirc 20 \text { to } 40 \bigcirc 40 \text { to } 80 \bigcirc 8 \text { to } 100
$$

Fig. 3. Calanus finmarchicus. Egg production (eggs female ${ }^{-1} \mathrm{~d}^{-1}$ ) around Iceland, 1996 to 2002, during (A) winter (December to February), (B) April, (C) May and (D) June. The $400 \mathrm{~m}$ isobath is also shown

very low during winter $\left(<3 \mathrm{mg} \mathrm{chl} \mathrm{a} \mathrm{m}^{-2}\right)$. On the shelf, biomass build-up started in April, whereas in the offshore area, appreciable increase of chlorophyll a was observed about 1 mo later (May). In both environments, the average chlorophyll concentrations were

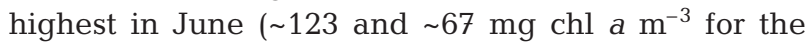
shelf and off-shelf stations, respectively).

During winter, the few females that were found both on and off the shelf were immature (Fig. 4B). In April, most females on the shelf were mature $(\sim 85 \%)$, while only $\sim 25 \%$ of those offshore were. In May, $>80 \%$ of the females were fully mature in both shelf and off-shelf waters. In June, the proportion of mature females had increased on the shelf $(\sim 95 \%)$, but decreased off the shelf $(\sim 70 \%)$.

On the SW shelves, average egg production rates were highest in June ( 45 eggs female $\left.{ }^{-1} \mathrm{~d}^{-1}\right)$, whereas in the offshore area the highest rates were observed in May ( $\sim 35$ eggs female ${ }^{-1} \mathrm{~d}^{-1}$; Fig. $\left.4 \mathrm{C}\right)$. On the shelf, average clutch sizes were highest in June ( $\sim 55$ eggs clutch $\left.^{-1}\right)$, whereas offshore average clutch sizes peaked in May ( 55 eggs clutch $^{-1}$; Fig. 4D). On the shelf, the proportion of spawning females from April to June ranged between 48 and $72 \%$, being highest in June (Fig. 4E). Farther from shore the proportion of spawning females increased from $\sim 27 \%$ in April to $\sim 70 \%$ in June.

To summarise, SW of Iceland, appreciable egg production started earlier onshore (April) than offshore (May), and the period of reproductive activity lasted longer on the shelf ( $\sim 3 \mathrm{mo}$, April to June) than farther from land ( 2 mo, May to June) (Figs. $3 \& 4$ ).

Fig. 5 shows integrated phytoplankton biomass (0 to $30 \mathrm{~m}$ ) and the egg production rates of Calanus finmarchicus averaged over all stations occupied in May, from 1999 to 2002, when all 3 hydrographic domains around Iceland were sampled (Atlantic, Atlantic/Arctic and Arctic Domains; Fig. 1). In the figure the data are divided into subregions with respect to this division. Phytoplankton biomass south and west of Iceland

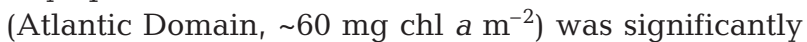
lower than in the north (Atlantic/Arctic Domain, $\sim 170 \mathrm{mg} \mathrm{chl} \mathrm{a} \mathrm{m}{ }^{-2}$ ) and east (Arctic Domain, $115 \mathrm{mg}$ chl $a_{\mathrm{m}^{-2}}$ ) (1-way ANOVA, Tukey's test, $\left.\mathrm{p}<0.01\right)$. Similarly, daily egg production rates were significantly lower in the Atlantic Domain (26 eggs female ${ }^{-1} \mathrm{~d}^{-1}$ ) than in the Atlantic/Arctic and Arctic Domains ( $\sim 35$ eggs female ${ }^{-1} \mathrm{~d}^{-1}$, in both environments) (egg production rates in the Atlantic/Arctic and Arctic Domains pooled, 1-way ANOVA, $\mathrm{p}<0.02$ ). 

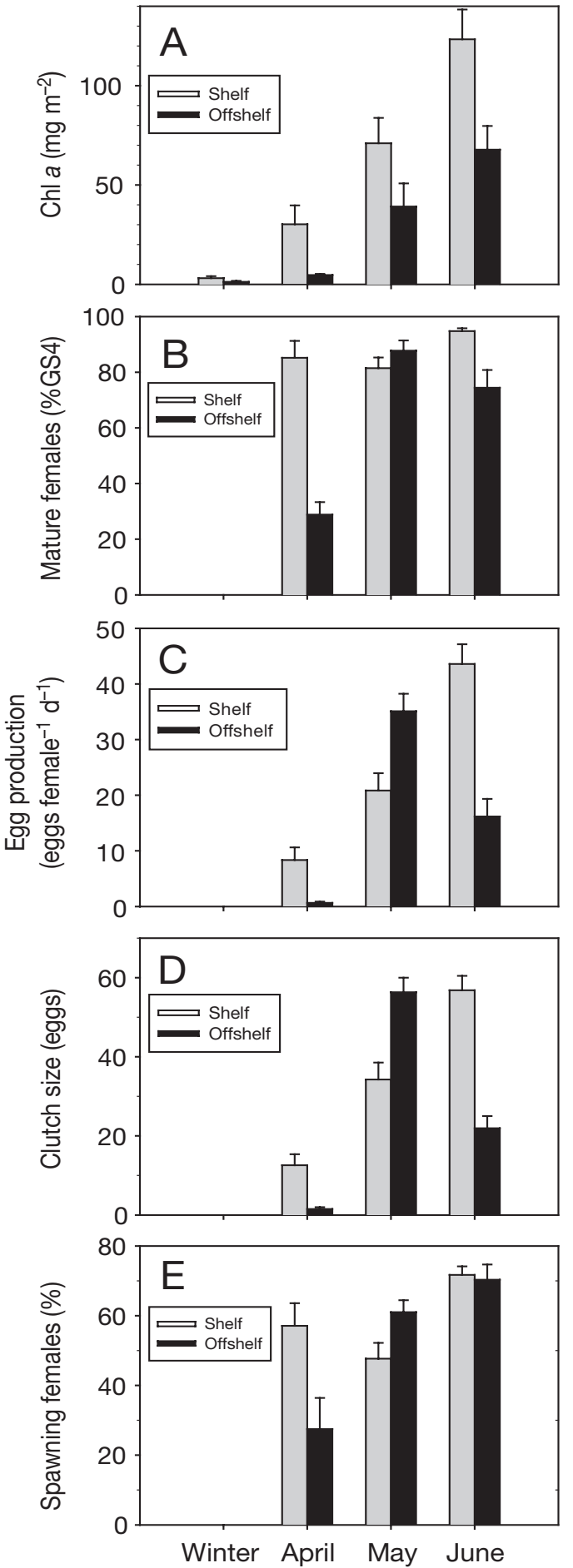

Fig. 4. Calanus finmarchicus. Reproductive parameters SW of Iceland, 1996 to 2002. (A) Chlorophyll $a$ (mg m${ }^{-2}$, integrated for 0 to $30 \mathrm{~m})$, (B) relative frequency of mature females $(\%)$, (C) egg production rates (eggs female $\mathrm{e}^{-1} \mathrm{~d}^{-1}$ ), (D) clutch size (eggs), (E) proportion of spawning females within $24 \mathrm{~h}$ after capture (\%). The data are average values for all stations in the Atlantic Domain (Fig. 1) divided into those taken inshore $(<400 \mathrm{~m})$ and offshore $(>400 \mathrm{~m})$. Vertical lines show standard errors
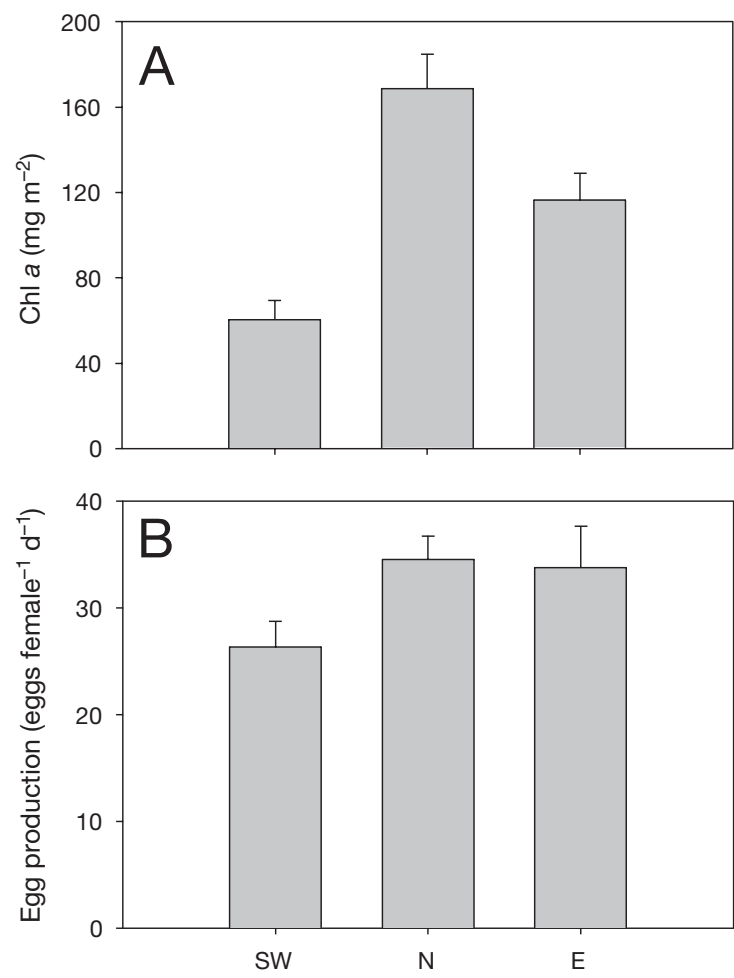

Fig. 5. (A) Average biomass of chlorophyll a $\left(\mathrm{mg} \mathrm{m}^{-2}\right.$, integrated for 0 to $30 \mathrm{~m}$ ) and (B) egg production rates of Calanus finmarchicus (eggs female ${ }^{-1} \mathrm{~d}^{-1}$ ). The data are average values for all stations in May 1999 to 2002, divided into those taken in the Atlantic Domain (SW), Atlantic/Arctic Domain (N) and Arctic Domain (E) (see Fig. 1). Vertical lines show standard errors

\section{Effect of temperature, chlorophyll a and prosome length on fecundity}

Exploratory data analysis using simple linear regressions suggested that egg production rates were positively related to food (integrated chlorophyll a concentrations) and body size (prosome length), whileopposite to expectations - negatively related to ambient temperatures (Fig. 6, Table 3). However, the effects of temperature on egg production rates may be outweighed by the fact that both prosome length and chlorophyll concentrations decreased with increasing temperatures (Fig. 6, Table 3).

It is reasonable to assume that all of these factors (body size, food and temperature) act together to affect the egg production rates of Calanus finmarchicus. In order to explore this, a stepwise forward multiple linear regression analysis was carried out, with egg production as the dependent variable and temperature, chlorophyll $a$ and prosome length as independent variables (Table 4). As intercorrelation among the independent variables is of low mag- 


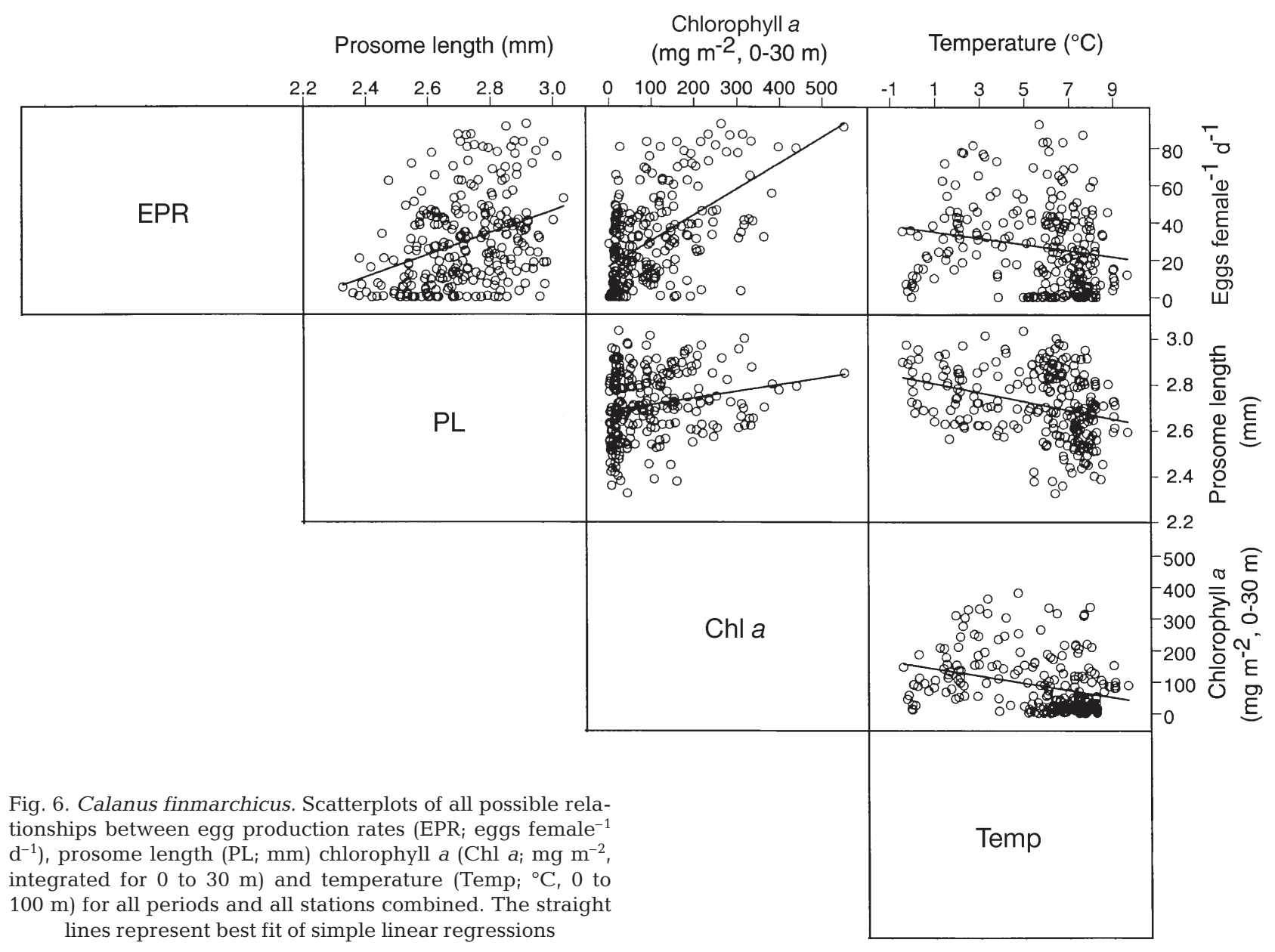

nitude (Table 3), this will not seriously affect the reliability of the estimated regression coefficients (Zar 1984). The result of this analysis showed that egg production rates were positively related to phytoplankton biomass and body size, while unrelated to temperature. The partial regression coefficients further showed that the egg production rates were more related to chlorophyll $a$ than to female size (Table 4). The fact that including prosome length in the model only increased the explained variance by $\sim 6 \%$ (from $\sim 31$ to $\sim 37 \%$, Table 4 ) also illustrates that it is not very important. When the multiple regression analysis was repeated with the data split up according to time of year, no relation between egg production and any of the independent variables was found either during winter or in April. In May, only chlorophyll contributed to the variation in egg production rates
Table 3. Calanus finmarchicus. Results from simple linear regression analyses between egg production rates $\left(E P R\right.$; eggs female $\left.{ }^{-1} \mathrm{~d}^{-1}\right)$, prosome length (PL; $\mathrm{mm}$ ), chlorophyll a (Chl $a_{;} \mathrm{mg} \mathrm{m}^{-2}$, integrated for 0 to $30 \mathrm{~m}$ ) and temperature (Temp, ${ }^{\circ} \mathrm{C}, 0$ to $100 \mathrm{~m}$ ). The regression coefficients (coefficient), sample size (n) and proportion of variance explained $\left(\mathrm{r}^{2}\right)$ are given together with their respective significance levels $(\mathrm{p})$

\begin{tabular}{|lccccc|}
\hline $\begin{array}{l}\text { Dependent } \\
\text { variable }\end{array}$ & $\begin{array}{c}\text { Independent } \\
\text { variable }\end{array}$ & Coefficient & $\mathrm{n}$ & $\mathrm{r}^{2}$ & $\mathrm{p}$ \\
\hline EPR & PL & 59.2 & 261 & 0.127 & $<0.0001$ \\
& Chl $a$ & 0.13 & 252 & 0.309 & $<0.0001$ \\
PL & Temp & -1.78 & 243 & 0.0339 & $<0.01$ \\
& Temp & -0.1 & 243 & 0.104 & $<0.0001$ \\
Chl $a$ & Chl $a$ & 0.000296 & 252 & 0.039 & $<0.01$ \\
& Temp & -12.43 & 243 & 0.100 & $<0.0001$ \\
\hline
\end{tabular}


Table 4. Calanus finmarchicus. Results of stepwise forward multiple linear regression analysis, with daily egg production rate $\left(E P R_{i}\right.$ eggs female $\left.{ }^{-1} \mathrm{~d}^{-1}\right)$ as the dependent variable and integrated chlorophyll concentration (0 to $30 \mathrm{~m})\left(\mathrm{Chl} a_{i} \mathrm{mg} \mathrm{m}^{-2}\right.$ ), prosome length ( $\mathrm{PL} ; \mathrm{mm}$ ) and surface layer temperature $\left(\mathrm{Temp}_{i}{ }^{\circ} \mathrm{C}, 0\right.$ to $\left.100 \mathrm{~m}\right)$ as independent variables. The standardised partial regression coefficients (Beta) and the change in variance explained $\left(\mathrm{r}^{2}\right.$ changed) caused by adding the respective variables to the model are given, together with their respective significance levels (p). The regression model (excluding the non-significant independent variable Temp), together with the sample size (n), proportion of variance explained $\left(\mathrm{r}^{2}\right)$ and significance (p) is also given

\begin{tabular}{lllrll}
\hline Dep & $\begin{array}{l}\text { Variable } \\
\text { entered }\end{array}$ & Beta & $\begin{array}{c}\mathrm{r}^{2} \\
\text { changed }\end{array}$ & $\mathrm{p}$ & Regression equation \\
\hline EPR & Chl $a$ & 0.524 & 0.309 & $<0.001$ & EPR $=0.125 \mathrm{chl} a+42.513 \mathrm{PL}-98.046$ \\
& PL & 0.275 & 0.063 & $<0.001$ & $\left(\mathrm{n}=231, \mathrm{r}^{2}=0.372, \mathrm{p}<0.001\right)$ \\
& Temp & 0.070 & 0.004 & 0.222 & \\
\hline
\end{tabular}

Iceland, with several values in the range of 2000 to $12000 \mathrm{mg} \mathrm{C} \mathrm{m}^{-2}$. North and NE of Iceland biomass was relatively low during this time, with biomass at most stations ranging between 100 and $500 \mathrm{mg} \mathrm{C} \mathrm{m}^{-2}$. In June, the highest values SW of Iceland $\left(\sim 1000\right.$ to $\left.6000 \mathrm{mg} \mathrm{C} \mathrm{m}{ }^{-2}\right)$ were still being observed over the shelves, whereas values were relatively low in the offshore areas (range $\sim 100$ to $1500 \mathrm{mg} \mathrm{C} \mathrm{m}^{-2}$ ) (Fig. 7D).

Southwest of Iceland during winter, April and June, biomass was similar on the shelf and off the shelf (1-way ANOVA, p > 0.05), whereas,

\section{Biomass}

The biomass of Calanus finmarchicus in the upper $100 \mathrm{~m}$ of the water column was very low during winter and early spring, with values ranging between $\sim 5$ and $60 \mathrm{mg} \mathrm{C} \mathrm{m}^{-2}$ during winter and $\sim 20$ and $500 \mathrm{mg} \mathrm{C} \mathrm{m}^{-2}$ in April (Fig. 7A,B). In May, the biomass had increased significantly, especially over the shelves south and west of Iceland and in the offshore areas east and SE of in May, biomass was significantly higher on the shelf than in the offshore area (1-way ANOVA, p < 0.01) (Fig. 8). On the shelf, biomass peaked in May $\left(\sim 2200 \mathrm{mg} \mathrm{C} \mathrm{m}^{-2}\right)$, whereas, in the offshore area, biomass was highest in May and June, with 780 and $\sim 850 \mathrm{mgC} \mathrm{m}{ }^{-2}$, respectively. Averaged over whole study period, biomass was $>2$ times higher on the shelf $\left(\sim 1500 \mathrm{mg} \mathrm{C} \mathrm{m}^{-2}\right)$ than in the offshore area $\left(\sim 600 \mathrm{mg} \mathrm{C} \mathrm{m}^{-2}\right)$.
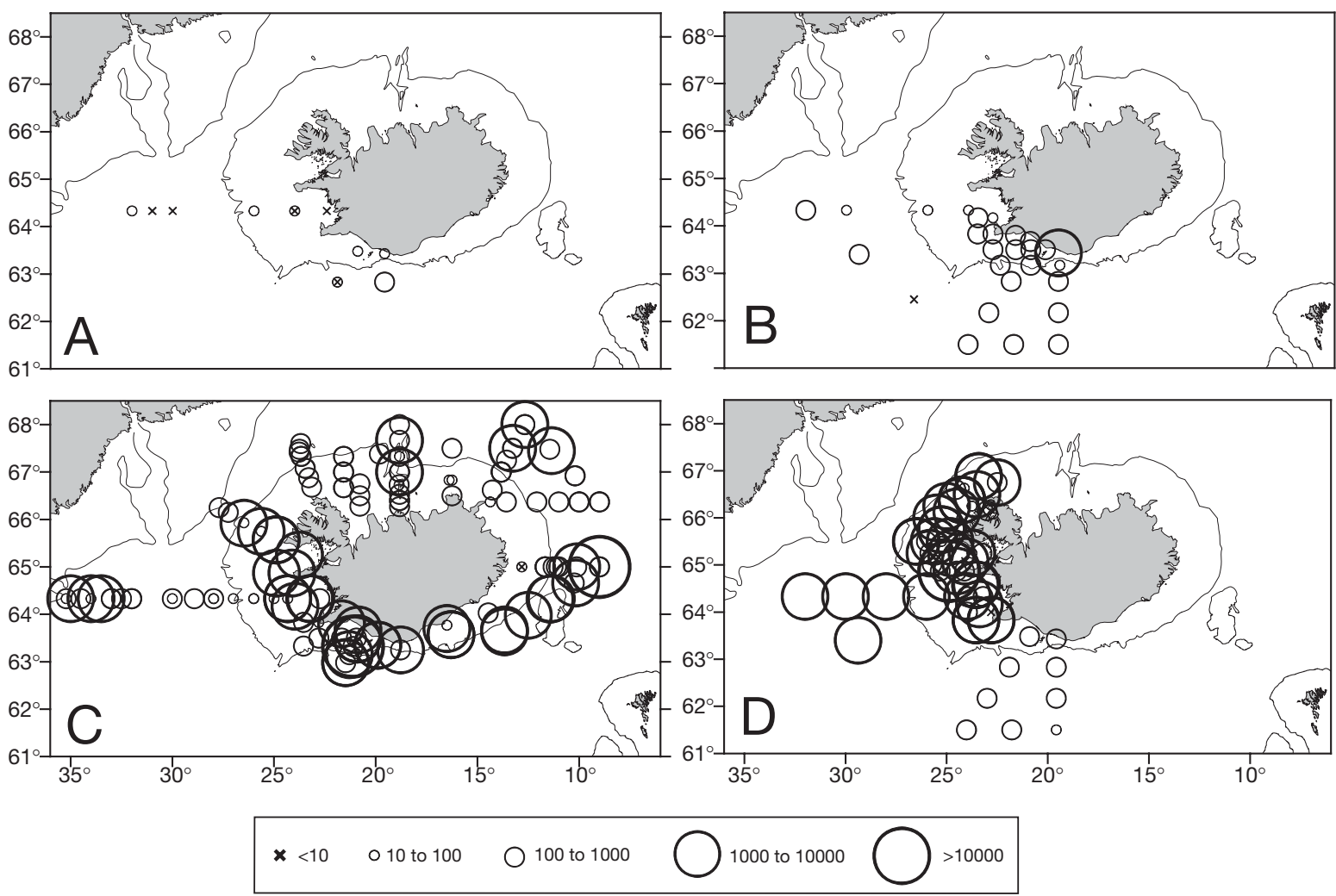

Fig. 7. Calanus finmarchicus. Biomass ( $\mathrm{mg} \mathrm{C} \mathrm{m}^{-2}$, integrated for 0 to $100 \mathrm{~m}$ ) around Iceland, 1996 to 2002, during (A) winter (December to February), (B) April, (C) May and (D) June. The $400 \mathrm{~m}$ isobath is also shown 


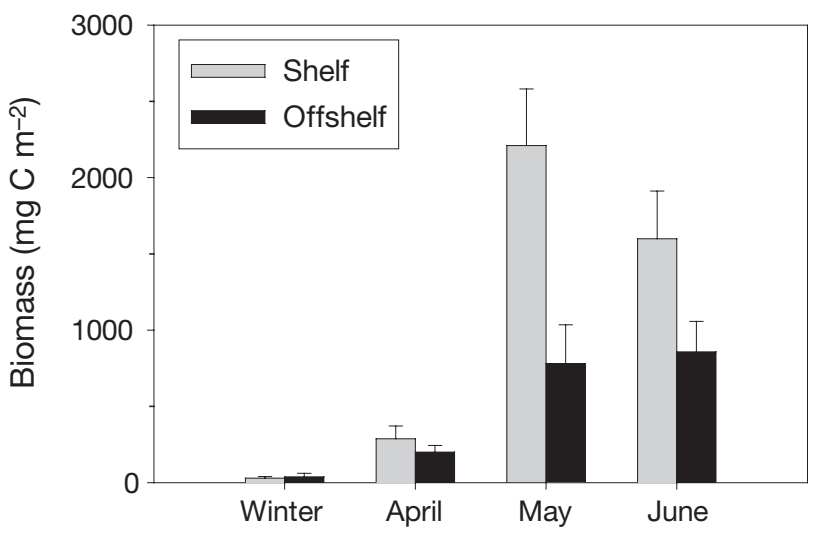

Fig. 8. Calanus finmarchicus. Biomass $\left(\mathrm{mg} \mathrm{C} \mathrm{m}^{-2}\right.$, integrated for 0 to $100 \mathrm{~m}$ ). The data are average values for all stations in the Atlantic Domain (Fig. 1), divided into those taken inshore $(<400 \mathrm{~m})$ and offshore $(>400 \mathrm{~m})$. Vertical lines show standard errors

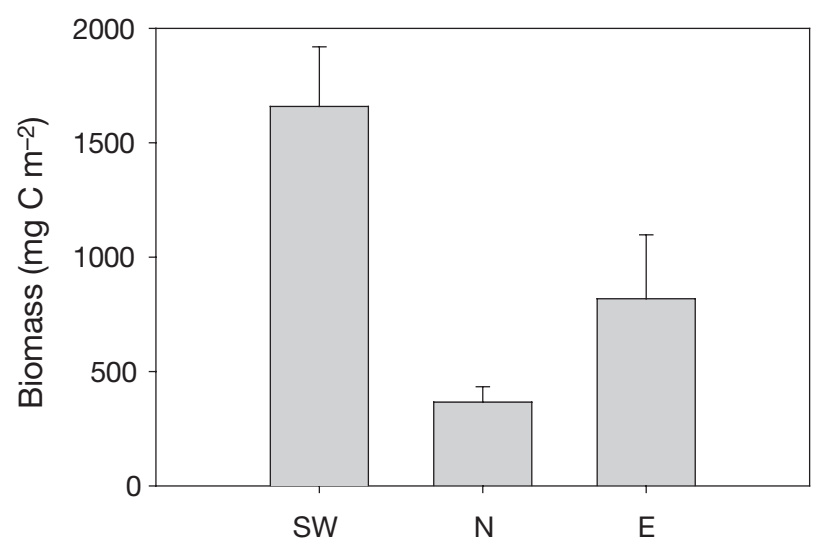

Fig. 9. Calanus finmarchicus. Biomass $\left(\mathrm{mg} \mathrm{C} \mathrm{m}^{-2}\right.$, integrated for 0 to $100 \mathrm{~m}$ ). The data are average values for all stations taken in May 1999 to 2002, divided into those collected in the Atlantic Domain (SW), Atlantic/Arctic Domain (N) and Arctic Domain (E) (see Fig. 1). Vertical lines show standard errors

Fig. 9 shows the biomass of Calanus finmarchicus, averaged over all stations occupied in May, from 1999 to 2002. In the figure the data are divided into 3 subregions with respect to hydrographic conditions (Atlantic, Atlantic/Arctic and Arctic Domains; Fig. 1). The biomass of $C$. finmarchicus was significantly higher in the Atlantic Domain $\left(\sim 1660 \mathrm{mg} \mathrm{C} \mathrm{m}^{-2}\right)$ than in both the Atlantic/Arctic Domain $\left(\sim 360 \mathrm{mg} \mathrm{C} \mathrm{m}^{-2}\right)$ and the Arctic Domain ( 810 $\mathrm{mg} \mathrm{C} \mathrm{m}^{-2}$ ) (1-way ANOVA, Tukey's test, $\mathrm{p}<0.05)$.

\section{Secondary production and grazing}

Secondary production and grazing potential by Calanus finmarchicus was calculated from specific egg production rates, biomass of $C$. finmarchicus and chlorophyll a standing stock (Table 5). For the same reasons as discussed above for the seasonal changes in the reproductive biology of $C$. finmarchicus (Fig. 4), the data are separated into those collected inshore $(<400 \mathrm{~m})$ and offshore $(>400 \mathrm{~m})$, and the analysis is confined to the SW region (Atlantic Domain; Fig. 1).

Average daily production was higher on the shelf than in the offshore area during April and June (Table 5) (1-way ANOVA, $\mathrm{p}<0.05)$. On the shelf, production was highest in June $\left(\sim 127 \mathrm{mg} \mathrm{C} \mathrm{m}^{-2} \mathrm{~d}^{-1}\right)$, whereas, in the offshore areas, production peaked in May $\left(\sim 46 \mathrm{mg} \mathrm{C} \mathrm{m}^{-2} \mathrm{~d}^{-1}\right)$. Averaged over the growth season (April to June), the secondary production was $>2$ times higher over the shelves $\left(\sim 76 \mathrm{mg} \mathrm{C} \mathrm{m}^{-2} \mathrm{~d}^{-1}\right)$ than in the offshore areas $\left(\sim 27 \mathrm{mg} \mathrm{C} \mathrm{m}^{-2} \mathrm{~d}^{-1}\right)$.

In April, Calanus finmarchicus was only capable of grazing $\sim 2 \%$ of the standing stock of phytoplankton on the shelf and $<1 \%$ off the shelf (Table 5). In May, the potential grazing impact had increased: it was $\sim 16$ to $17 \%$ of the phytoplankton standing stock in both environments. In June, the potential grazing impact on the shelf was similar to that in the previous month $(\sim 16 \%)$, whereas it had decreased off the shelf $(\sim 8 \%)$.

Table 6 shows the secondary production and potential grazing impact of Calanus finmarchicus, averaged over all stations occupied in May, from 1999 to 2002. In the figure the data are divided into 3 subregions with respect to hydrographic conditions (Atlantic, Atlantic/Arctic and Arctic Domains; Fig. 1). Although not statistically significant (1-way ANOVA, $p>0.05$ ), the estimated secondary production of $C$. finmarchicus appeared higher in the Atlantic Domain $\left(\sim 76 \mathrm{mg} \mathrm{C} \mathrm{m}^{-2} \mathrm{~d}^{-1}\right)$ than in both the Atlantic/Arctic Domain $\left(\sim 35 \mathrm{mg} \mathrm{C} \mathrm{m}^{-2} \mathrm{~d}^{-1}\right)$ and the Arctic Domain $\left(\sim 55 \mathrm{mg} \mathrm{C} \mathrm{m}^{-2} \mathrm{~d}^{-1}\right)$. Similarly, the potential grazing impact by $C$. finmarchicus in May was on average much higher south and west of Iceland ( 16\%) than north and east of the island (3 to $7 \%$ ) (1-way ANOVA, Tukey's test, $\mathrm{p}<0.01$ ).

\section{DISCUSSION}

\section{Phytoplankton development}

SW of Iceland, the growth of phytoplankton began earlier on the shelves (April) than farther from shore (May) (Fig. 2). This accords with previous studies showing that the spring bloom in Icelandic waters generally culminates earlier in nearshore waters (April to May) than in offshore areas (May to June) due to earlier stratification in the former region (Thordardottir \& Stefansson 1977, Stefansson \& Gudmundsson 1978, Thordardottir 1986, Gislason \& Astthorsson 1991, Gudmundsson 1998, Astthorsson \& Gislason 1999). 
Table 5. Calanus finmarchicus. Specific egg production, and estimated secondary production and grazing impact. See 'Materials and methods' for details of the calculations. The table shows average values $( \pm \mathrm{SE})$ and ranges for all stations in the Atlantic Domain (Fig. 1) divided into those taken inshore $(<400 \mathrm{~m})$ and offshore $(>400 \mathrm{~m})$

\begin{tabular}{|c|c|c|c|c|c|c|c|}
\hline & \multirow[t]{2}{*}{ Area } & \multicolumn{2}{|c|}{$\begin{array}{l}\text { Specifc egg production } \\
\left(\mathrm{d}^{-1}\right)\end{array}$} & \multicolumn{2}{|c|}{$\begin{array}{l}\text { Secondary production } \\
\quad\left(\mathrm{mg} \mathrm{C} \mathrm{m}^{-2} \mathrm{~d}^{-1}\right)\end{array}$} & \multicolumn{2}{|c|}{$\begin{array}{c}\text { Potential grazing impact } \\
\text { (\% phytoplankton biomass } \mathrm{d}^{-1}\end{array}$} \\
\hline & & Mean $( \pm \mathrm{SE})$ & Range & Mean $( \pm$ SE $)$ & Range & Mean $( \pm \mathrm{SE})$ & Range \\
\hline \multirow[t]{2}{*}{ Winter } & Shelf & 0.000 & - & 0.0 & - & 0.0 & - \\
\hline & Offshelf & 0.0 & - & 0.0 & - & 0.0 & - \\
\hline \multirow[t]{2}{*}{ April } & Shelf & $0.026 \pm 0.040$ & $0.001-0.091$ & $6.3 \pm 2.1$ & $0.0-29.4$ & $2.2 \pm 0.6$ & $0.0-7.5$ \\
\hline & Offshelf & $0.002 \pm 0.013$ & $0.000-0.007$ & $0.2 \pm 0.1$ & $0.0-0.7$ & $0.3 \pm 0.1$ & $0.0-1.6$ \\
\hline \multirow[t]{2}{*}{ May } & Shelf & $0.056 \pm 0.036$ & $0.000-0.220$ & $94.5 \pm 24.5$ & $0.0-713.5$ & $15.7 \pm 4.7$ & $0.0-128.2$ \\
\hline & Offshelf & $0.080 \pm 0.055$ & $0.013-0.156$ & $46.4 \pm 11.3$ & $1.0-282.0$ & $17.2 \pm 5.3$ & $0.1-110.0$ \\
\hline \multirow[t]{2}{*}{ June } & Shelf & $0.101 \pm 0.041$ & $0.008-0.213$ & $127.0 \pm 20.6$ & $0.2-606.5$ & $15.9 \pm 5.9$ & $0.0-321.1$ \\
\hline & Offshelf & $0.038 \pm 0.056$ & $0.015-0.104$ & $34.1 \pm 9.7$ & $1.9-114.7$ & $8.3 \pm 4.1$ & $0.1-50.7$ \\
\hline
\end{tabular}

Table 6. Calanus finmarchicus. Specific egg production and estimated secondary production and grazing impact. See 'Materials and methods' for details of the calculations. The data are average values $( \pm$ SE) and ranges for all stations in May, divided into those taken in the Atlantic (SW), Atlantic/Arctic (N) and Arctic Domains (E) (Fig. 1)

\begin{tabular}{|c|c|c|c|c|c|c|}
\hline & \multicolumn{2}{|c|}{ Specific egg production } & \multicolumn{2}{|c|}{$\begin{array}{c}\text { Secondary production } \\
\left(\mathrm{mg} \mathrm{C} \mathrm{m}^{-2} \mathrm{~d}^{-1}\right)\end{array}$} & \multicolumn{2}{|c|}{$\begin{array}{l}\text { Potential grazing impact } \\
\text { (\% phytoplankton biomass } \mathrm{d}^{-1} \text { ) }\end{array}$} \\
\hline & Mean $( \pm \mathrm{SE})$ & Range & Mean $( \pm \mathrm{SE})$ & Range & Mean $( \pm$ SE) & Range \\
\hline SW & $0.065 \pm 0.006$ & $0.000-0.220$ & $75.9 \pm 15.8$ & $0.0-713.5$ & $16.2 \pm 3.6$ & $0.0-128.2$ \\
\hline $\mathrm{N}$ & $0.085 \pm 0.006$ & $0.001-0.160$ & $35.3 \pm 6.8$ & $0.0-166.5$ & $2.8 \pm 1.2$ & $0.0-41.1$ \\
\hline E & $0.079 \pm 0.009$ & $0.000-0.211$ & $55.2 \pm 22.1$ & $0.0-869.7$ & $7.1 \pm 3.2$ & $0.0-114.4$ \\
\hline
\end{tabular}

\section{Reproduction}

Spawning of Calanus finmarchicus started earlier on the shelf (April) than farther from land (May). This is supported by the gonad maturation data, showing that almost all females found on the shelf in April were mature ( $85 \%$ ) compared to only $\sim 25 \%$ of those found off the shelf (Fig. 4B), and also by the data on egg production rates (Fig. 4C), clutch size (Fig. 4D) and proportion of spawning females (Fig. 4E). These data substantiate previous findings, based on seasonal stage distributions, of an earlier timing of the spring spawning of $C$. finmarchicus in nearshore waters than farther from shore (Gislason \& Asthorsson 1996, 1998a, Astthorsson and Gislason 1999). The main overwintering habitats of $C$. finmarchicus are located in the deep ocean basins surrounding Iceland (Gislason \& Astthorsson 2000, Heath et al. 2000, Gislason 2002). The animals start their upward migration in March, and by April a significant proportion of the overwintering animals in the offshore areas have ascended to the surface; from here a part of the populations is advected onto the shelves (Gislason \& Astthorsson 2000). The phytoplankton concentrations observed over the shelves in April ( 4 to $160 \mathrm{mg} \mathrm{chl} \mathrm{a} \mathrm{m}{ }^{-2}$; Fig. 2) probably sufficed to support the relatively low rates of egg production observed then ( 0 to 30 eggs female ${ }^{-1} \mathrm{~d}^{-1}$ ) (Niehoff et al. 1999, Richardson et al. 1999, Campbell \& Head 2000), whereas in the offshore areas the concentrations in April ( 3 to $\left.7 \mathrm{mg} \mathrm{chl} \mathrm{a} \mathrm{m}^{-2}\right)$ may have been too low to initiate spawning.

On the shelves SW of Iceland, the highest egg production rates were observed at the end of the study in June ( 45 eggs female ${ }^{-1} \mathrm{~d}^{-1}$; Fig. 4C). However, as no observations were made in July, it remains unknown if these rates represent the seasonal maximum. However, as judged by conclusions based on abundance and stage composition data (main reproductive period in April to June; Gislason \& Astthorsson 1996, 1998b, 2002), the egg production rates observed in June on the shelves probably represented the seasonal maximum. In the offshore areas, the highest rates were observed in May ( 35 eggs female $\left.{ }^{-1} \mathrm{~d}^{-1}\right)$, with lower rates in April and June (Fig. 4C). Thus, the present results indicate that, on the shelves SW of Iceland, maximum spawning activity of Calanus finmarchicus generally occurs in June, whereas in the offshore areas this takes place in May.

The average rates of egg production observed in the present study in May and June, when the egg production rates were highest (35 to 45 eggs female ${ }^{-1} \mathrm{~d}^{-1}$; Fig. 1C), were similar to those observed during bloom 
conditions at Weathership $M$ in the Norwegian Sea (14 to 44 eggs female ${ }^{-1} \mathrm{~d}^{-1}$; Niehoff et al. 1999), in Atlantic waters of the Barents Sea (24 to 44 eggs female $^{-1} \mathrm{~d}^{-1}$; Melle \& Skjoldal 1998), and in the Labrador Sea $($ mean $\pm \mathrm{SD}=47.3 \pm 22.4$; Head et al. 2000).

\section{Factors affecting egg production rates}

Over the large temporal and spatial scales of the present study, the egg production rates were positively related to both phytoplankton biomass and body size, while essentially independent of mean surface layer temperatures (Table 4). The close coupling between the spawning of Calanus finmarchicus and phytoplankton growth has been documented previously by several workers (see Hirche 1996 for review). In the present study, only a relatively small part of the variance could be explained by chlorophyll a $(\sim 31 \%$ Table 4). One reason might be that the chlorophyll $a$ measurements are only a measure of the quantity of potential phytoplankton food, and they do not take into account other food parameters that may influence egg production rates, such as food quality (particle size and species composition) and heterotrophic feeding (see Harris 1996 for review). The past feeding history of females may also influence the egg production rates. Contrary to small copepods, C. finmarchicus uses its lipid storage to produce eggs after ascent from overwintering (Niehoff et al. 1999, Harris et al. 2000, ReyRassat et al. 2002). Therefore, the egg production rates would be a function of lipid storage as well as availability of suitable fresh food. Lipids begin to accumulate in stages C3 to C4 (Hirche 1996), and the egg production rates may therefore be influenced by the food environment that the females were experiencing as copepodites during the previous year before they went into diapause.

Laboratory studies have shown that, in addition to food, body size and ambient temperatures affect egg production rates of Calanus finmarchicus (e.g. Runge \& Plourde 1996, Hirche et al. 1997). Female size is believed to affect egg production by influencing clutch size (Runge \& Plourde 1996), while temperature affects egg production by influencing the frequency of spawning (Hirche 1990, Hirche et al. 1997). The inverse relationship between temperature and egg production according to the simple linear regression (Fig. 6, Table 3) and the lack of relationship in the multiple regression (Table 4) are therefore surprising. However, as discussed by Halsband \& Hirche (2001), it may be difficult to discern the effects of these factors independently in the field, where the effects of one factor may be overridden by the other. For instance, the present study shows that female size decreased with increasing temperatures (Fig. 6, Table 3). Therefore, the expected increase in fecundity due to increasing temperatures may be overridden by the decrease in female size. As shown in Fig. 6 and Table 3, chlorophyll a also decreased with increasing temperatures, and this may also have contributed to the apparent lack of relationship between ambient temperature and egg production. Similar to our findings for $C$. finmarchicus, Harris et al. (2000) found a negative relationship between egg production rates and temperature for C. helgolandicus. However, they were able to remove the negative effect by eliminating data from the hottest months with dinoflagellates from their data set, suggesting that, in addition to temperature, the composition of the diet also affects the egg production rates.

In the oceanic area NE of Iceland, where the effects of the cold Arctic East Icelandic Current are most pronounced (Fig. 1), egg production rates were generally low, while still significant ( $\sim 0$ to 20 eggs female ${ }^{-1} \mathrm{~d}^{-1}$; Fig. 3C). Whether Calanus finmarchicus is able to reproduce in Arctic Water has been subject to some controversy. Thus, Tande et al. (1985) proposed that the cold temperature regime was the reason that the species did not reproduce successfully in the Arctic Water of the Barents Sea. However, high egg production rates observed at negative temperatures, both in the Greenland Sea (Hirche 1990) and on the Scotian Shelf and in the Labrador Sea (Campbell \& Head 2000), suggest that temperature as such may not be the limiting factor for the reproductive success of $C$. finmarchicus in arctic conditions. Perhaps, the relatively low egg production rates in the Arctic Water NE of Iceland (Fig. 3C) are related to long starvation periods in Arctic Water due to the relatively short period of phytoplankton growth generally observed there (Gudmundsson 1998).

\section{Biomass, secondary production and grazing}

SW of Iceland, both the average biomass and the estimated secondary production of Calanus finmarchicus were $>2$ times higher over the shelves than in the offshore area (Fig. 8, Table 5). Biomass and secondary production in May were also generally much higher in the warm Atlantic waters south and west of Iceland than in the colder waters off the north and east coasts (Fig. 9, Table 6). It is reasonable to assume that the regional variability in biomass and secondary productivity of $C$. finmarchicus around Iceland is related to differences in primary productivity around the island. Thus, the data on phytoplankton distribution show that the phytoplankton biomass is generally greater over 
the shelves than farther offshore (Fig. 4A). And, as discussed by Thordardottir (1994), this is also where the primary production tends to be highest. Although the distribution of phytoplankton biomass between hydrographic domains around Iceland in May (Fig. 5A) is not reflected in the biomass of C. finmarchicus (Fig. 9), long-term investigations around Iceland have shown that the average annual primary production is relatively high south and west of Iceland, but low north and east of the island (Thordardottir 1994). This supports the suggestion of a bottom-up control of the productivity of $C$. finmarchicus in Icelandic waters, with primary production acting as an important factor influencing the productivity of the species.

An interesting finding of the present study is that, although egg production and growth rates were higher in the Atlantic/Arctic and the Arctic Domains than in the Atlantic Domain during May (Fig. 5B, Table 6), biomass and estimated secondary production were not (Fig. 9, Table 6). In fact, both biomass and secondary production were lower in the former regions as compared to the latter. These results suggest that mortality or export of populations is higher north and east of Iceland than off the south and west coasts. Off the north coast, this uncoupling between egg production (growth rates) and biomass was greatest (Figs. 5B \& 9, Table 6). A factor in this may be that the area north of Iceland serves as the summer feeding area for capelin Mallotus villosus, which, with an average stock size of 1900 thousand tonnes (Vilhjalmsson 1994), is by far the largest planktivorous fish stock in Icelandic waters. Calanus finmarchicus, as an important part of the diet of capelin (Astthorsson \& Gislason 1997), and the relatively low biomass and secondary production of $C$. finmarchicus in the northern regions may therefore, at least partly, be caused by predation from capelin.

The present study is the first attempt to estimate secondary productivity and production of Calanus finmarchicus around Iceland, and therefore no previous data from Icelandic waters are available that are directly comparable to the ones presented here. However, studies on seasonal dynamics of C. finmarchicus around Iceland (Astthorsson \& Gislason 1992, 2003, Gislason \& Astthorsson 1996, 1998b, 2002, Gislason et al. 2000), as well as long-term investigations on the distribution of zooplankton biomass in Icelandic waters (Astthorsson et al. 1983, Astthorsson \& Gislason 1992, 1995), clearly show that the biomass of C. finmarchicus is relatively high in the warm waters south and west of Iceland compared to the colder waters of the north and east coasts. This accords with the results of the present study. Based on the long-term distribution of biomass, the earlier workers further suggested that the productivity of $C$. finmarchicus was higher in the warmer waters south and west of Iceland, compared to the colder waters off the north and east coasts, an assertion that is also supported by the biomass and production estimates of the present study (Fig. 9, Table 6).

Iceland lies at the boundary between 2 of the largest distribution centres of Calanus finmarchicus in the North Atlantic, the Labrador Sea and the Norwegian Sea (Aksnes \& Blindheim 1996, Planque et al. 1997, Bucklin et al. 2000). In the Labrador Sea, the biomass of C. finmarchicus, integrated from 0 to $100 \mathrm{~m}$, ranges between $\sim 1000$ and $2000 \mathrm{mg} \mathrm{C} \mathrm{m}^{-2}$ during spring and summer (Head et al. 2003), whereas, in the Norwegian Sea, a value of $\sim 800$ to $1300 \mathrm{mg} \mathrm{C} \mathrm{m}^{-2}$ over the depth range 0 to $500 \mathrm{~m}$ has been reported (Timokhina 1964, Aksnes \& Blindheim 1996) (calculated from dry weights presented in these papers using a conversion factor of $50 \%$ carbon). Thus, the spring and summer biomass of $C$. finmarchicus in the open waters off Iceland ( 1500 to $3000 \mathrm{mg} \mathrm{C} \mathrm{m}^{-2}$; Figs. $7 \&$ 9), appears at least as high as in the main distribution centres of the species.

One of the goals of the present study was to increase knowledge on the secondary production and grazing by Calanus finmarchicus in Icelandic waters. Although several workers have previously used egg production as an estimator of Calanus growth rates in other sea areas (e.g. Hirche et al. 1994, 2001, Nielsen \& Hansen 1995, Rysgaard et al. 1999, Madsen et al. 2001, Maar et al. 2002, Richardson et al. 2003), it is also increasingly recognised that specific egg production rates may underestimate secondary production, firstly, because females may not invest all surplus energy into reproduction and, secondly, because specific egg production rates may not be equal to somatic growth rates of the juveniles (e.g. Harris et al. 2000, Rey-Rassat et al. 2002, Hirst \& Bunker 2003). An additional complication may arise from the fact that the weight of females decreases while spawning (Hirst \& McKinnon 2001). As to the grazing estimates, a further complication may be that the carbon to chlorophyll ratio was held constant when converting chlorophyll to carbon, although the ratio may vary through the seasons. Because of all this, the values for secondary production and grazing by Calanus finmarchicus presented here (Tables 5 \& 6) should only be considered as rough estimates rather than absolute values.

Comparison with other field measurements does, however, indicate that the production values estimated in this study are generally similar to those reported in the literature from other areas dominated by Calanus finmarchicus. Thus, in oceanic waters at Weathership M, using 3 different methods (of which 1 was the egg production method), Hirche et al. (2001) estimated the secondary production of C. finmarchicus during the period from April to June as 30 to $56 \mathrm{mg} \mathrm{C} \mathrm{m}^{-2} \mathrm{~d}^{-1}$, which is similar to the values we found in off-shelf 
waters SW of Iceland during the same period of the year ( $27 \mathrm{mg} \mathrm{C} \mathrm{m}^{-2} \mathrm{~d}^{-1}$; Table 5$)$. In the northern North Sea, Fransz \& Diel (1985) reported average secondary production during April and May as $\sim 44 \mathrm{mg} \mathrm{C} \mathrm{m}^{-2} \mathrm{~d}^{-1}$, which compares with shelf estimates reported in this paper during the same time of year $\left(\sim 50 \mathrm{mg} \mathrm{C} \mathrm{m}^{-2} \mathrm{~d}^{-1}\right.$; Table 5).

On average, about 16 to $17 \%$ of the daily phytoplankton stock was grazed by Calanus finmarchicus when the grazing pressure was highest (Table 5). By assuming a doubling time of $1 \mathrm{~d}^{-1}$ for the phytoplankton, this suggests that $C$. finmarchicus was generally not able to control the primary production during spring and summer. The fact that the average phytoplankton biomass did not increase more rapidly off the shelf than on the shelf from May to June (Fig. 4A), in spite of the decreasing grazing rates during this period in the former area (Table 5), also supports this. Thus, a major part of the phytoplankton production during spring and summer appears to be channelled through other zooplankters or to settle ungrazed to the bottom, fuelling the benthic food chains. However, the range in grazing estimates was very broad (Table 5), and, locally, the values for the potential grazing impact of $C$. finmarchicus on phytoplankton standing stock were much higher than indicated by the average values presented in Table 5. Thus, in May and June, values $>100 \%$ were estimated at several stations, especially in the offshore area east of the island and on the SW and western shelves, suggesting that in these areas the animals were able to control the primary production. Under these conditions, C. finmarchicus secondary production must have been based on another source in addition to phytoplankton carbon, i.e. heterotrophic feeding and/or internal energy (lipid) reserves.

Acknowledgements. I would like to thank the crews of the research vessels 'Arni Fridriksson' and 'Bjarni Sæmundsson' and my colleagues at the Marine Research Institute for their assistance during sampling of the material. I also thank A. R. Bödvarsdottir, G. S. Jonsson, H. Petursdottir and I. G. Jonsdottir for their meticulous analysis of the samples. Thanks also to A. Jaworski for statistical advice. Finally, I want to thank the anonymous referees for their helpful comments. This work was supported in part by the Icelandic Republic Fund and the European Commission through the TASC project (Contract No. MAS3-CT95-0039).

\section{LITERATURE CITED}

Aksnes DL, Blindheim J (1996) Circulation patterns in the North Atlantic and possible impact on the population of Calanus finmarchicus. Ophelia 44:7-28

Astthorsson OS, Gislason A (1992) Investigations on the ecology of the zooplankton community in Isafjord-deep, northwest Iceland. Sarsia 77:225-236

Astthorsson OS, Gislason A (1995) Long-term changes in zoo- plankton biomass in Icelandic waters in spring. ICES J Mar Sci 52:657-688

Astthorsson OS, Gislason A (1997) On the food of capelin in the subarctic waters north of Iceland. Sarsia 82:81-86

Astthorsson OS, Gislason A (1999) Inter-annual variation in abundance and development of Calanus finmarchicus in Faxafloi, West Iceland. Rit Fiskideildar 16:131-140

Astthorsson OS, Gislason A (2003) Seasonal variations in abundance, development and vertical distribution of Calanus finmarchicus, C. hyperboreus and C. glacialis in the East Icelandic Current. J Plankton Res 25:843-854

Astthorsson OS, Hallgrimsson I, Jonsson GS (1983) Variations in zooplankton densities in Icelandic waters in spring during the years 1961-1982. Rit Fiskideildar 7:73-113

Beare DJ, Gislason A, Astthorsson OS, McKenzie E (2000) Assessing long-term changes in early summer zooplankton communities around Iceland. ICES J Mar Sci 57: 1545-1561

Berggreen U, Hansen B, Kiørboe T (1988) Food size spectra, ingestion and growth of the copepod Acartia tonsa during development: implications for determination of copepod production. Mar Biol 99:341-352

Bucklin A, Astthorsson OS, Gislason A, Allen LD, Smolenack SB, Wiebe PH (2000) Population genetic variation of Calanus finmarchicus in Icelandic waters: preliminary evidence of genetic differences between Atlantic and Arctic populations. ICES J Mar Sci 57:1592-1604

Campbell RW, Head EJH (2000) Egg production rates of Calanus finmarchicus in the western North Atlantic: effect of gonad maturity, female size, chlorophyll concentration, and temperature. Can J Fish Aquat Sci 57:518-529

Diel S, Tande KS (1992) Does the spawning of Calanus finmarchicus in high latitudes follow a reproducible pattern? Mar Biol 113:21-31

Fransz HG, Diel S (1985) Secondary production of Calanus finmarchicus (Copepoda: Calanoides) in a transitional system of the Fladen Ground area (northern North Sea) during the spring of 1983. In: Gibbs PE (ed) Proc 19th Eur Mar Biol Symp. Cambridge University Press, Cambridge, p 123-133

Gislason A (2002) Ecology of zooplankton in Icelandic waters with special reference to Calanus finmarchicus. $\mathrm{PhD}$ thesis, University of Oslo, Oslo

Gislason A, Astthorsson OS (1991) Distribution of zooplankton across the Coastal Current southwest of Iceland in relation to hydrography and primary production. ICES CM 1991/L:17:1-23

Gislason A, Astthorsson OS (1996) Seasonal development of Calanus finmarchicus along an inshore-offshore gradient southwest of Iceland. Ophelia 44:71-84

Gislason A, Astthorsson OS (1998a) Variability in the population structure of Calanus finmarchicus in Icelandic waters in spring. ICES J Mar Sci 55:811-813

Gislason A, Astthorsson OS (1998b) Seasonal variations in biomass, abundance and composition of zooplankton in the subarctic waters north of Iceland. Polar Biol 20:85-94

Gislason A, Astthorsson OS (2000) Winter distribution, ontogenetic migration and rates of egg production of Calanus finmarchicus southwest of Iceland. ICES J Mar Sci 57: $1727-1739$

Gislason A, Astthorsson OS (2002) The food of Norwegian spring spawning herring in the western Norwegian Sea in relation to the annual cycle of zooplankton. Sarsia 87: $236-247$

Gislason A, Astthorsson OS, Petursdottir H, Gudfinnsson $\mathrm{H}$, Bödvarsdottir AR (2000) Life cycle of Calanus finmarchicus south of Iceland in relation to hydrography and chloro- 
phyll a. ICES J Mar Sci 57:1619-1627

Gudmundsson K (1998) Long-term variation in phytoplankton productivity during spring in Icelandic waters. ICES J Mar Sci 55:635-643

Halsband C, Hirche HJ (2001) Reproductive cycles of dominant calanoid copepods in the North Sea. Mar Ecol Prog Ser 209:219-229

Hansen B, Østerhus S (2000) North Atlantic-Norwegian Sea exchanges. Prog Oceanogr 45:109-208

Hansen PJ, Björnsen PK, Hansen BW (1997) Zooplankton grazing and growth: scaling within the $2-2,000-\mu \mathrm{m}$ body size range. Limnol Oceanogr 36:708-728

Harris RP (1996) Feeding ecology of Calanus. Ophelia 44: 85-109

Harris RP, Irigoien X, Head RN, Rey C and 5 others (2000) Feeding, growth, and reproduction in the genus Calanus. ICES J Mar Sci 57:1708-1726

Head EJH, Harris LR, Campbell RW (2000) Investigations on the ecology of Calanus spp. in the Labrador Sea. I. Relationship between the phytoplankton bloom and reproduction and development of Calanus finmarchicus in spring. Mar Ecol Prog Ser 193:53-73

Head EJH, Harris LR, Yashayaev I (2003) Distributions of Calanus spp. and other mesozooplankton in the Labrador Sea in relation to hydrography in spring and summer (1995-2000). Prog Oceanogr 59:1-30

Heath MR, Fraser JG, Gislason A, Hay SJ, Jonasdottir SH, Richardson K (2000) Winter distribution of Calanus finmarchicus in the northeast Atlantic. ICES J Mar Sci 57: 1628-1635

Hirche HJ (1990) Egg production of Calanus finmarchicus at low temperature. Mar Biol 106:53-58

Hirche HJ (1996) The reproductive biology of the marine copepod, Calanus finmarchicus-a review. Ophelia 44: 111-128

Hirche HJ, Hagen W, Mumm N, Richter C (1994) The Northeast Water Polynya, Greenland Sea. III. Meso- and macroplankton distribution and production of dominant herbivorous copepods during spring. Polar Biol 14:491-503

Hirche HJ, Meyer U, Niehoff B (1997) Egg production of Calanus finmarchicus: effect of temperature, food and season. Mar Biol 127:609-620

Hirche HJ, Brey T, Niehoff B (2001) A high frequency time series at Ocean Weather Ship Station M (Norwegian Sea): population dynamics of Calanus finmarchicus. Mar Ecol Prog Ser 219:205-219

Hirst AG, Bunker AJ (2003) Growth of marine planktonic copepods: global rates and patterns in relation to chlorophyll $a$, temperature, and body weight. Limnol Oceanogr 48:1988-2010

Hirst AG, McKinnon AD (2001) Does egg production represent adult female copepod growth? A call to account for body weight changes. Mar Ecol Prog Ser 223:179-199

Laabir M, Poulet SA, Ianora A (1995) Measuring production and viability of eggs in Calanus helgolandicus. J Plankton Res 17:1125-1142

Longhurst A, Williams R (1992) Carbon flux by seasonal vertical migrant copepods is a smaller number. J Plankton Res 11:1495-1509

Maar M, Nielsen TG, Richardson K, Christaki U, Hansen OS, Zervoudaki S, Christou ED (2002) Spatial and temporal variability of food web structure during the spring bloom in the Skagerrak. Mar Ecol Prog Ser 239:11-29

Madsen SD, Nielsen TG, Hansen BW (2001) Annual population development and production by Calanus finmarchicus, C. glacialis and C. hyperboreus in Disco Bay, western Greenland. Mar Biol 139:75-93
Marshall SM, Orr AP (1972) The biology of a marine copepod (reprint). Springer-Verlag, Berlin

Melle W, Skjoldal HR (1998) Reproduction and development of Calanus finmarchicus, C. glacialis and C. hyperboreus in the Barents Sea. Mar Ecol Prog Ser 169:211-228

Motoda S (1959) Devices of simple plankton apparatus. Mem Fac Fish Hokkaido Univ 7:73-94

Niehoff B, Hirche HJ (1996) Oogenesis and gonad maturation in the copepod Calanus finmarchicus and the prediction of egg production from preserved samples. Polar Biol 16: 601-612

Niehoff B, Klenke U, Hirche HJ, Irigoien X, Head R, Harris R (1999) A high frequency time series at Weathership $M$, Norwegian Sea, during the 1997 spring bloom: the reproductive biology of Calanus finmarchicus. Mar Ecol Prog Ser 176:81-92

Nielsen TG, Hansen B (1995) Plankton community structure and carbon cycling on the western coast of Greenland during and after the sedimentation of a diatom bloom. Mar Ecol Prog Ser 125:239-257

Ohman MD, Runge JA (1994) Sustained fecundity when phytoplankton resources are in short supply: omnivory by Calanus finmarchicus in the Gulf of St Lawrence. Limnol Oceanogr 39:21-36

Planque B, Hays GC, Ibanez F, Gamble JC (1997) Large scale spatial variation in the seasonal abundance of Calanus finmarchicus. Deep-Sea Res 44:315-326

Plourde S, Runge JA (1993) Reproduction of the planktonic copepod Calanus finmarchicus in the lower St Lawrence estuary: relation to the cycle of phytoplankton production and evidence for a Calanus pump. Mar Ecol Prog Ser 102: $217-227$

Rey-Rassat C, Irigoien X, Harris R, Head R, Carlotti F (2002) Egg production rates of Calanus helgolandicus females reared in the laboratory: variability due to present and past feeding conditions. Mar Ecol Prog Ser 238:139-151

Richardson AJ, Verheye HM, Mitchell-Innes BA, Fowler JL, Field JG (2003) Seasonal and event-scale variation in growth of Calanus agulhensis (Copepoda) in the Benguela upwelling system and implications for spawning of sardine Sardinops sagax. Mar Ecol Prog Ser 254:239-251

Richardson K, Jonasdottir SH, Hay SJ, Christoffersen A (1999) Calanus finmarchicus egg production and food availability in the Faroe-Shetland Channel and northern North Sea: October-March. Fish Oceanogr 8:153-162

Runge JA, Plourde S (1996) Fecundity characteristics of Calanus finmarchicus in coastal waters of eastern Canada. Ophelia 44:171-187

Runge JA, Roff JC (2000) The measurement of growth and reproductive rates. In: Harris RP, Wiebe P, Lenz J, Skjoldal HR, Huntley M (eds) ICES zooplankton methodology manual. Academic Press, San Diego, p 401-454

Rysgaard S, Nielsen TG, Hansen BW (1999) Seasonal variation in nutrients, pelagic primary production and grazing in a high-Arctic coastal marine ecosystem, Young Sound, Northeast Greenland. Mar Ecol Prog Ser 179:13-25

Stefansson U (1962) North Icelandic waters. Rit Fiskideildar 3: $1-269$

Stefansson U, Gudmundsson G (1978) The freshwater regime of Faxafloi, southwest Iceland, and its relationship to meteorological variables. Estuar Coast Mar Sci 6:535-551

Strickland JDH, Parsons TR (1968) A practical handbook of seawater analysis. Bull Fish Res Board Can 167:1-311

Tande KS, Hassel A, Slagstad D (1985) Gonad maturation and possible life cycle strategies in Calanus finmarchicus and Calanus glacialis in the northwestern part of the Barents Sea. In: Gray JS, Christiansen M (eds) Marine biology of 
polar regions and the effects of stress on marine organisms. John Wiley \& Sons, Chichester, p 141-157

Thordardottir T (1986) Timing and duration of spring blooming south and southwest of Iceland. In: Skreslet S (ed) The role of freshwater outflow in coastal marine ecosystems. Springer-Verlag, Berlin, p 345-360

Thordardottir T (1994) Plöntusvif og frumframleidni í sjonum vid Ísland (Phytoplankton and primary production in Icelandic waters). In: Stefansson U (ed) Islendingar hafid og audlindir thess (Icelanders, the sea and its resources). Visindafelag Islendinga (Societas scientarium Islandica), Reykjavík, p 65-88 (in Icelandic)

Thordardottir T, Stefansson U (1977) Productivity in relation

Editorial responsibility: Otto Kinne (Editor-in-Chief)

Oldendorf/Luhe, Germany to environmental variables in the Faxafloi region 1966-1967. ICES CM 1977/L:34:1-26

Timokhina AF (1964) On zooplankton production in different water masses of the Norwegian Sea. Tr Polar Res Inst Mar Fish Oceanogr, Murmansk (PINRO) 16:165-182 (in Russian)

Valdimarsson H, Malmberg S-Aa (1999) Near-surface circulation in Icelandic waters derived from satellite tracked drifters. Rit Fiskideildar 16:23-39

Vilhjálmsson H (1994) The Icelandic capelin stock. Rit Fiskideildar 13:1-281

Zar JH (1984) Biostatistical analysis, 2nd edn. Prentice-Hall, Englewood Cliffs, NJ

Submitted: March 26, 2004; Accepted: September 14, 2004

Proofs received from author: January 3, 2005 